\title{
ANALISIS KEBIJAKAN PENANGANAN COVID-19 \\ DARI PERSPEKTIF SOCIOLOGICAL JURISPRUDENCE
}

\author{
Sapto Hermawan, Herman
}

\author{
Fakultas Hukum Universitas Sebelas Maret Surakarta \\ Prodi Pendidikan Pancasila dan Kewarganegaraan, Fakultas Ilmu Sosial, \\ Universitas Negeri Makassar, Kampus UNM Gunung Sari Jl. AP. Pettarani Makassar, \\ Sulawesi Selatan, 90221 \\ Email: saptohermawan_fh@staff.uns.ac.id;
}

\begin{abstract}
As an affected COVID-19 pandemic country, Indonesia took policy options through Social Restrictions on Large-Scale (PSBB), supported by six legal documents from Government Regulation in Lieu-of-The Law, Government Regulations, to Presidential Decrees. This sociolegal research aims to analyze the COVID-19 countermeasure policy through Roscoe Pound's sociological jurisprudence. Base on empirical data from March to December 2020, the results showed that the policy to overcome COVID-19 is supported by six legal documents when examined through analysis of the hierarchy of norms, clarity of the purpose and usefulness very contradictory to the purpose of the deployment restrictions of COVID-19 itself. Referring to sociological jurisprudence, the COVID-19 policies should be based on four essential elements adjusted to public requirements so that the implementation of the policies can perform effectively.
\end{abstract}

Key words: The COVID-19 policy, Sociological Jurisprudence

\begin{abstract}
Abstrak
Sebagai negara yang terdampak pandemic Covid-19, Indonesia mengambil opsi kebijakan melalui Pembatasan Sosial Berskala Besar yang ditopang oleh enam produk hukum mulai Peraturan Pemerintah Pengganti Undang-Undang, Peraturan Pemerintah, sampai dengan Keputusan Presiden. Penelitian sosio-legal ini bertujuan menganalisis kebijakan penanganan COVID-19 melalui penggunaan teori sociological jurisprudence Roscoe Pound. Berdasarkan data penelitian dari Maret sampai dengan Desember tahun 2020, hasil penelitian menunjukan bahwa kebijakan penanganan COVID-19 yang didukung oleh enam produk hukum apabila dikaji secara hierarki norma, kejelasan tujuan, dan kemanfaatan ternyata kontradiktif dengan tujuan membatasi ruang gerak sebaran virus COVID-19 itu sendiri. Selanjutnya mendalilkan kepada aliran sociological jurisprudence maka kebijakan penanganan COVID-19 seyogyanya disandarkan kepada empat poin mendasar yang disesuaikan dengan kebutuhan publik sehingga implemenetasi kebijakan penanganan COVID-10 dapat berjalan dengan efektif.
\end{abstract}

Kata Kunci: Kebijakan Penanganan COVID-19, Sociological Jurisprudence 


\section{Latar Belakang}

\section{Corona Virus Disease (selanjutnya} disebut COVID-19) tergolong sebagai infeksi virus yang sangat menular sehingga secara cepat telah bertransformasi menjadi pandemi global, di mana sampai detik ini belum berhasil ditemukan vaksin atau obat mujarab untuk melumpuhkannya. Jumlah angka yang terinfeksi oleh COVID-19 secara global telah menyentuh jutaan orang dengan tingkat kematian yang telah mencapai ratusan ribu. Melansir dari beberapa pemberitaan media cetak maupun onlinenasional, awal penyebaran COVID-19 di Indonesia ditanggapi oleh pemerintah secara beragam, dan cenderung bias atau kontraproduktif penanganannya. Pandemi ini acapkali menjadi bahan seloroh dari beberapa pejabat kementerian, bahwa Indonesia tidak akan terinfeksi COVID-19. Kebijakan yang mengarah pada pemberian insentif termasuk fasilitas diskon yang ditawarkan oleh maskapai penerbangan, tempat-tempat wisata yang masih dibuka untuk umum pada awal masuknya COVID-19 ini di Indonesia merupakan beberapa contoh logika keekonomian yang kontra produktif ditengah pandemi global akibat COVID-19. Pemerintah Indonesia di awal pandemi cenderung abai terhadap hal ini, padahal sudah menjadi rahasia umum bahwasanya Pemerintah Indonesia selain memiliki keterbatasan terkait kemampuan anggaran ${ }^{1}$, Pemerintah Indonesia juga memiliki keterbatasan dalam penguasaan ilmu pengetahuan dan teknologi kedokteran, bahkan ditambah dengan kebijakan penanganan COVID-19 yang cenderung tidak tegas.

Dalam rangka mengatasi persebaran COVID-19 yang semakin luas serta tujuan mengurangi jumlah penderita terinfeksi maka Pemerintah Indonesia kemudian memilih metode sendiri melalui kebijakan Pembatasan Sosial Berskala Besar (selanjutnya disebut PSBB) yang ditopang oleh 6 produk hukum yang dikeluarkan secara berurutan mulai Peraturan Pemerintah Pengganti UndangUndang (selanjutnya disebut Perppu), Peraturan Pemerintahan (selanjutnya disebut PP), sampai dengan Keputusan Presiden (selanjutnya disebut Keppres). Jika kebijakan ini dicermati dari pandangan analitisme hukum Roscoe Pound, maka analisis terhadap produk hukum tersebut sebagai quod principi placuit, legis habet vigore, ${ }^{2} \mathrm{di}$ mana regulasi yang tampak dianggap sudah menyelesaikan segala persoalan. Realitasnya, kendati regulasi sudah dijalankan namun paparan angka statistik menunjukan jumlah

1 Pendapatan negara masih mengandalkan sektor pajak sebagai tumpuan utama, yang direncanakan sebesar Rp.,1.865.702.816.382.000,- penerimaan negara bukan pajak sebesar Rp.,366.995.145.278.000,- dan hibah direncanakan sebesar Rp.,498.740.000.000,- Undang-Undang Nomor 20 Tahun 2019 tentang Anggaran Pendapatan dan Belanja Negara.

2 James A. Ballentine, Ballentine's Law Dictionary, (Indianapolis: Bobbs-Merrill Company, 1916), p. 971 
pasien terinfeksi COVID-19 justru semakin bertambah. Relasi antara regulasi dengan kebijakan yang diambil Pemerintah Indonesia tersebut kemudian perlu dilakukan (1) analisis yuridis terkait dengan kebijakan penanganan COVID-19 terutama dalam hal inkonsistensi regulasi yang telah dikeluarkan dari aspek hierarki norma, ketaatan asas, kemanfaatan, dan kepastian hukum dan (2) menganalisis kebijakan penanganan COVID-19 dari sudut pandang teori sociological jurisprudence Roscoe Pound. Penyusunan artikel ini disuguhkan dengan menggunakan metode penelitian sosio-legal ${ }^{3}$, di mana secara fundamental bertujuan untuk menganalisis kebijakan penanganan COVID-19 melalui penggunaan teori sociological jurisprudence dari Roscoe Pound. Indikator esensi dari teori sociological jurisprudence kemudian dijadikan parameter untuk bahan analisis terhadap data yang diperoleh. Data penelitian diambil dari kebijakan yang diterapkan oleh Pemerintah dari bulan Maret sampai dengan Desember 2020.

\section{Pembahasan}

\section{A. Kajian Terhadap Kebijakan Penanganan COVID-19 di Indonesia}

Pembahasan atas kebijakan penanganan COVID-19 di Indonesia pada bagian ini bertujuan mengkaji berbagai macam atau disparitas kebijakan hukum pemerintah yang dikeluarkan. Kebijakan hukum yang dikeluarkan pemerintah mulai dari Perpuu, PP, dan Keppres. Selain itu, berkenaan juga dengan dasar hukum (legalitas) keluarnya PP, dan Keppres. Legalitas atau dasar hukum keluarnya kebijakan penanganan COVID-19 ini oleh pemerintah dapat dilihat dari undangundang yang mendasari kebijakan hukum tersebut $^{4}$, atau secara konseptual dikenal dengan wet en rechtmatigheid van bestuurs. ${ }^{5}$

1. Strategi Kebijakan Penanganan COVID-19 di Indonesia (Maret -Desember 2020)

Pilihan penanganan yang diambil oleh pemerintah dalam hal ini PSBB, di mana PSBB merupakan pembatasan aktivitas

3 socio-legal researchers increasingly recognise the need to employ a wide variety of methods in studying law and legal phenomena...the objective of this exercise is ultimately to combine konowledge, skill, and forms of research experinece from two (or several) disciplines to transcend some of the theoretical and methodological limitations of the discipliners in question and create a basis for developing a new form of analysis. Lihat Reza Banakar and Max Travers, "Law, Sociology, and Method" in Theory and Method in Socio-Legal Research, edited by Reza Banakar and Max Travers, (Oxford; Hart Publishing, 2005), p. 4. atau dalam bahasa lain "research cast as a mirror is intended to "reflect" and articulate aspects of the complex realities of contemporary policing policy and practice. Its role is to describe, account for, and explain how and why policing engages with social problems and social orders in particular ways", lihat Martin Innes, "The Art, Craft, and Science of Policing", in The Oxford Handbook of Empirical Legal Research, edited by Peter Cane and Herbert M. Kritzer, (Oxford: Oxford University Press, 2010), p.13

4 Pasal 20 Ayat (1), (2), (3), (4), dan (5), kaitannya dengan Pasal 5 Ayat (2) UUD NRI 1945. Terkait dengan Perpuu itu sendiri, lihat Pasal 22 Ayat (1) UUD NRI 1945, menentukan bahwa dalam hal ikhwal kegentingan yang memaksa, presiden berhak menetapkan peraturan pemerintah sebagai pengganti undang-undang.

5 Segala tindakan pemerintah berdasarkan pada peraturan perundang-undangan, dan hukum yang berlaku. 
tertentu masyarakat dalam suatu area atau wilayah yang diduga terinfeksi penyakit termasuk yang terkontaminasi untuk mencegah kemungkinan penyebaran penyakit atau kontaminasi tersebut. ${ }^{6}$ Poin utama pembatasan dalam PSBB ini terkait dengan aktifitas masyarakat dibatasi sedemikian rupa. Artinya, kegiatan atau aktifitas sosial-ekonomi masih dimungkinkan dengan pembatasanpembatasannya.

Opsi penanganan pada dasarnya dapat ditempuh dengan ragam cara dan mekanisme, selain memilih dengan PSBB. Mekanisme itu, seperti misalnya dapat ditempuh, dengan isolasi, karantina rumah, karantina rumah sakit, dan karantina wilayah. ${ }^{7}$ Pengertian karantina atau isolasi memiliki perbedaan yang mendasar dengan PSBB, karantina atau isolasi poin utamanya adalah pemisahan atau pembatasan orangnya atau masyarakat yang bersangkutan, sedangkan PSBB adalah pembatasan aktifitas dari orang atau masyarakat tersebut. PSBB dalam hal ini dapat dianalogikan dengan istilah social distancing, namun dengan skala yang lebih besar. Artinya, secara terbatas atau mengurangi, dan membatasi berbagai aktifitas masyarakat di dalam ruang sosial ekonominya, misalnya, menjaga jarak fisik minimal satu sampai dua meter, penumpang tidak boleh duduk di samping sopir atau penumpang berada di bagian belakang, bagi kendaraan berupa sepeda motor tidak boleh berboncengan, pesta pernikahan tidak boleh melibatkan kerumunan orang, dan lain sebagainya. PSBB paling sedikit meliputi, peliburan sekolah dan tempat kerja, pembatasan kegiatan keagamaan dan/atau pembatasan kegiatan di tempat atau fasilitas umum. Pembatasan dilakukan dengan tetap memperhatikan aspek pendidikan, produktivitas kerja, dan ibadah, dan/ atau tetap menjaga pemenuhan kebutuhan dasar penduduk. ${ }^{8}$

Sebagaimana dikemukakan Solly Lubis, ${ }^{9}$ secara teoritis kebijakan merupakan seperangkat keputusan yang dijalankan oleh pelaku politik untuk mencapai tujuan, termasuk cara untuk mencapai tujuan yang dimaksudkan. Kebijakan memiliki perbedaan dengan kebijaksanaan atau kearifan (wisdom). Kebijaksanaan merupakan pemikiran, atau sebagai pertimbangan yang mendalam sebagai dasar dari perumusan kebijakan. Pengertian kebijakan negara (state policy) oleh James Andreson sebagaimana yang dikutip Kusnardi dan Saragih $^{10}$ memiliki

6 Pasal 1 angka 11 Undang-Undang Negara Republik Indonesia Nomor 6 Tahun 2018 tentang Kekarantinaan Kesehatan (Lembaran Negara Republik Indonesia Tahun 2018 Nomor 128, Tambahan Lembaran Negara Republik Indonesia Nomor 6236), jo. Pasal 1 PP 21/2020.

7 Pasal 1 Undang-Undang Nomor 6 Tahun 2018 tentang Kekarantinaan Kesehatan.

8 Pasal 4 Ayat (1), (2), dan (3), terminologi hukumnya berbeda dengan pengertian Pasal 55 dalam UndangUndang Negara Republik Indonesia Nomor 6 Tahun 2018 tentang Kekarantinaan Kesehatan.

9 M. Solly Lubis, Kebijakan Publik, (Bandung: Mandar Maju, 2007), hlm. 5.

10 Negara dalam persepsi von Jhering memiliki monopoli kekuasaan fisik, memiliki hak istimewa menggunakan kekuasaan fisiknya, memaksakan warganya tunduk pada aturannya, mengangkat senjata membela tanah airnya, menentukan mata uang dan pajak, Moh. Kusnardi, dan Bintang R. Saragih, Ilmu Negara, (Jakarta: Gaya Media Pratama, 2008), hlm. 116-117. 
ciri-ciri yang menandainya. Ciri-ciri itu adalah mempunyai tujuan, berisi tindakan, tindakan nyata, mungkin positif atau negatif, dan selalu dituangkan dalam peraturan yang otoritatif. Kebijakan pemerintah pada dasarnya merupakan kewenangan mengalokasi nilai-nilai bagi masyarakat secara menyeluruh, dengan demikian yang mempunyai kewenangan mengatur seluruh kepentingan masyarakat adalah pemerintah, bukan lembaga lainnya. ${ }^{11}$

Dari sisi legalitas, sesuai dengan pandangan Solly Lubis dan James Andreson di atas, maka dasar hukum bagi pemerintah mengambil langkah penanganan COVID19, sudah tepat melalui Undang-Undang Nomor 6 Tahun 2018 tentang Kekarantinaan Kesehatan. Landasan yuridis ini menjadi dasar kewenangan yang dimiliki pemerintah untuk mengambil langkah kebijakan hukum melalui PP Nomor 21 Tahun 2020, dan Keppres Nomor 11 Tahun 2020, atau dengan kata lain, PP dan Kepres ini merupakan peraturan organik (peraturan pelaksanaan) dari UU Kekarantinaan Kesehatan. Selain dari dasar hukum atau legalitas ini, maka pilihan kebijakan hukum diambil sebagai bagian dari penanganan COVID-19, dan sebagai cara untuk mencapai tujuan yang dimaksudkan. ${ }^{12}$
Kebijakan hukum PSBB yang dilakukan oleh pemerintah berdasarkan strategi penanganan COVID-19 dengan jalan membuat pengaturan atau manajemen administrasi negara merupakan suatu legalitas $^{13}$ tindakan hukum pemerintahan. Pemerintah dalam kerangka penanganan COVID-19 telah membuat Peraturan Pemerintah Pengganti Undang-Undang Nomor 1 Tahun 2020 tentang Kebijakan Keuangan Negara dan Stabilitas Sistem Keuangan untuk Penananganan Pandemi Corona Virus Disease 2019 (COVID-19) dan/ atau dalam rangka Menghadapi Ancaman yang Membahayakan Perekonomian Nasional dan/atau Stabilitas Sistem Keuangan, tanggal 31 Maret 2020; Peraturan Pemerintah Nomor 21 Tahun 2020 tentang Pembatasan Sosial Berskala Besar dalam Rangka Percepatan Penanganan Corona Virus Disease 2019 (COVID-19), tanggal 31 Maret 2020; Keputusan Presiden Nomor 7 Tahun 2020 tentang Gugus Tugas Percepatan Penanganan Corona Virus Disease 2019 (COVID-19), tanggal 13 Maret 2020; Keputusan Presiden Nomor 9 Tahun 2020 tentang Perubahan atas Keputusan Presiden Nomor 7 Tahun 2020 tentang Gugus Tugas Percepatan Corona Virus Disease 2019 (COVID-19), tanggal 20

11 Ibid., hlm. 8. Lihat juga Sapto Hermawan, Herman, "Kajian Terhadap Tindakan Administrasi Pada Kekuasaan Yudikatif Pasca Berlakunya Undang-Undang Administrasi Pemerintahan", Jurnal Legislasi Indonesia, Vol. 18, No. 1, (2021): 59-80.

12 H. Sadjijono, Bab-bab Pokok Hukum Administrasi Negara, (Yogyakarta: LaksBang Pressindo, 2001), hlm. 86. Lihat dan bandingkan dengan Pasal 1 Undang-Undang Nomor 30 Tahun 2014 tentang Administrasi Pemerintahan (Lembaran Negara Republik Indonesia Tahun 2014 Nomor 292, Tambahan Lembaran Negara Republik Indonesia Nomor 5601).

13 Pasal 1 Ayat (3) UUD NRI 1945, lihat juga M. Nata Saputra, Hukum Administrasi Negara, (Jakarta: Rajawali, 1988), hlm. 28. 
Maret 2020; Keputusan Presiden Nomor 11 Tahun 2020 tentang Penetapan Kedaruratan Kesehatan Masyarakat Corona Virus Disease 2019 (COVID-19), tanggal 31 Maret 2020; dan Keputusan Presiden Republik Indonesia Nomor 12 Tahun 2020 tentang Penetapan Bencana Non-alam Penyebaran Corona Virus Disease 2019 (COVID-19), tanggal 13 April 2020.

Pilihan kebijakan PSBB ini tentu saja akan melahirkan hubungan hukum antara pemerintah selaku organisasi kekuasaan dengan masyarakat warga negara atau badan usaha baik badan hukum maupun bukan badan hukum dalam suasana perang melawan COVID-19. PSBB ini dapat dibedakan dengan karantina, oleh karena dalam karantina pemerintah pusat wajib menyediakan kebutuhan hidup dasar orang dan makanan hewan ternak yang berada di wilayah karantina, dengan melibatkan pemerintah daerah setempat termasuk pihakpihak yang terkait. ${ }^{14}$

2. Inkonsistensi Produk Hukum dalam Kebijakan Penanganan COVID-19

Kebutuhan masyarakat di tengah pandemi COVID-19 salah satunya adalah memerlukan peraturan perundang-undangan yang baik, agar legalitas serta legitimasi tindakan pemerintah dari masyarakat dapat dipertanggungjawabkan dihadapan hukum. ${ }^{15}$ Pemerintah wajib membuat kebijakan hukum atau membuat peraturan hukum yang dilaksanakan dengan cara dan metode yang pasti, baku, dan standar yang mengikat semua lembaga yang berwenang membentuk peraturan perundang-undangan, termasuk masyarakat di dalamnya.

Berikut dapat disampaikan analisis yuridis terhadap beberapa regulasi yang telah dikeluarkan pemerintah terkait dengan kebijakan penanganan COVID-19.

a. Peraturan Pemerintah Pengganti UndangUndang (Perppu)

Perppu Nomor 1 Tahun 2020 pada intinya adalah upaya pemerintah dalam rangka penanganan COVID-19, dan untuk menghadapi ancaman yang membahayakan perekonomian nasional dan/atau stabilitas sistem keuangan. ${ }^{16}$ Perppu dalam hal ini dikeluarkan oleh pemerintah karena anggapan ketiadaan peraturan perundang-undangan yang menjadi dasar dan legalitas tindakan pemerintah dalam rangka kebijakan keuangan negara dan stabilitas sistem keuangan untuk penanganan COVID-19 yang mengancam perekonomian dan stabilitas sistem keuangan. Anggapan pemerintah ini tidak sepenuhnya

14 Pasal 52, 55, dan 58 UU 6/2018, mewajibkan kepada pemerintah selama karantina memenuhi kebutuhan hidup dasar orang yang dikarantina, bandingkan dengan Pasal 59, tidak mencakup kewajiban pemerintah selama PSBB untuk memenuhi kebutuhan dasar orang.

15 Soehino, Ilmu Negara, (Yogyakarta: Liberty, 2005), Hlm. 9. Lihat Samidjo, Ilmu Negara, (Bandung: Armico, 1986), Hlm. 151.

16 Pasal 1 Ayat (3) Perppu Nomor 1 Tahun 2020, menentukan bahwa untuk melaksanakan Anggaran Pendapatan dan Belanja Negara (APBN) sebagaimana dimaksud pada ayat (1) dan ayat (2) dalam rangka penanganan pandemi Corona Virus Disease 2019 (covid-19), dan menghadapi ancaman yang membahayakan perekonomian nasional dan/atau stabilitas sistem keuangan. 
benar adanya, kondisi pandemi COVID-19 yang ada di Indonesia saat ini, pada dasarnya dapat didekati secara yuridis oleh pemerintah melalui Peraturan Pemerintah (PP), sebagai peraturan organik untuk melaksanakan berbagai Undang-Undang (UU) yang terkait, tanpa harus mengeluarkan Perppu ${ }^{17}$, kecuali dengan mengingat, bahwa keadaan kegentingan yang memaksa tersebut memang tidak ada sama sekali undang-undang yang dapat dijadikan dasar dan legalitas pemerintah dalam mengambil tindakan untuk mengatasi hal tersebut. ${ }^{18}$ Legalitas tindakan pemerintah untuk mengatasi keadaan keuangan negara dan stabilitas sistem keuangan negara di tengah pandemi COVID-19 dapat ditemukan legalitasnya diberbagai undang-undang yang terkait. Berikut tabel peraturan perundangundangan yang menjadi dasar hukum pemerintah dalam rangka menangani dampak ekonomi dalam masa pandemi COVID-19 tanpa harus mengeluarkan Perpuu lagi.

Jika dicermati lebih mendalam, Perppu Nomor 1 Tahun 2020 ini justru menyatakan beberapa pasal dalam berbagai undangundang dinyatakan tidak berlaku, contohnya Pasal 55 Ayat (4) Undang-Undang Nomor 23 Tahun 1999 tentang Bank Indonesia, yang menentukan bahwa Bank Indonesia dilarang membeli untuk diri sendiri surat-surat utang negara sebagaimana dimaksud pada ayat (1), kecuali di pasar sekunder. Terminologi pasal ini seharusnya dibaca oleh pemerintah, bahwa Bank Indonesia dilarang membeli untuk diri sendiri surat-surat utang negara dalam keadaan atau kondisi negara yang normal. Kondisi bencana nasional dan kedaruratan kesehatan masyarakat ${ }^{19}$ menjadi dasar dan legalitas pemerintah untuk mengambil tindakan pengecualian atas ketentuan Pasal 55 Ayat (4) Undang-Undang Nomor 23 Tahun 1999 tentang Bank Indonesia. Tindakan hukum pemerintah melalui pengecualiaan berlakunya Pasal 55 Ayat (4) Undang-Undang Nomor 23 Tahun 1999 tentang Bank Indonesia, termasuk pasal-pasal di berbagai undang-undang lainnya dengan demikian, dapat dilakukan dengan menerbitkan PP. ${ }^{20}$ Dasar hukum dan legalitas undang-undang tindakan pemerintah melalui PP pada pokoknya sudah ada, dengan menentukan pengecualian berlakunya atas berbagai pasal-pasal diberbagai undangundang tersebut a quo keadaan pandemi COVID-19 yang terjadi, dan menjaga stabilitas sistem keuangan negara.

17 Undang-Undang Dasar Negara Republik Indonesia Tahun 1945, pada Pasal 22 Ayat (1), menentukan, dalam hal ikhwal kegentingan yang memaksa, presiden berhak menetapkan peraturan pemerintah sebagai pengganti undang-undang, Ayat (2) Peraturan Pemerintah itu harus mendapat persetujuan Dewan Perwakilan Rakyat dalam persidangan yang berikut, Ayat (3) Jika tidak mendapat persetujuan, maka Peraturan Pemerintah itu harus dicabut.

18 Philipus M. Hadjon, dkk, Hukum Administrasi dan Tindak Pidana Korupsi, (Yogyakarta: Gadjah Mada University Press), 2012, Hlm. 6

19 Keppres Nomor 11 Tahun 2020, dan Keppres Nomor 12 Tahun 2020.

20 PP yang dimaksud oleh penulis adalah mengatur biaya yang dapat digunakan oleh pemerintah dalam rangka penanganan covid-19, dan untuk menjaga ancaman yang membahayakan perekonomian nasional dan/atau stabilitas sistem keuangan negara. 
Tabel 1. Dasar Hukum Pemerintah Menangani Dampak Ekonomi COVID-19

\begin{tabular}{|c|c|c|}
\hline No. & Produk Hukum & Obyek dan Subyek Pengaturan \\
\hline 1. & $\begin{array}{l}\text { Undang-Undang Nomor } 6 \text { Tahun } 1983 \\
\text { tentang Ketentuan Umum dan Tata Cara } \\
\text { Perpajakan sebagaimana telah beberapa kali } \\
\text { diubah terakhir dengan Undang-Undang } \\
\text { Nomor } 16 \text { Tahun } 2009\end{array}$ & $\begin{array}{l}\text { Penetapan Peraturan Pemerintah Pengganti } \\
\text { Undang-Undang Nomor } 5 \text { Tahun } 2008 \text { tentang } \\
\text { Perubahan Keempat atas Undang-Undang Nomor } \\
6 \text { Tahun } 1983 \text { tentang Ketentuan Umum dan Tata } \\
\text { Cara Perpajakan Menjadi Undang-Undang }\end{array}$ \\
\hline 2 & $\begin{array}{l}\text { Undang-Undang Nomor } 23 \text { Tahun } 1999 \\
\text { tentang Bank Indonesia sebagaimana } \\
\text { telah beberapa kali diubah terakhir dengan } \\
\text { Undang-Undang Nomor } 6 \text { Tahun } 2009\end{array}$ & $\begin{array}{l}\text { Penetapan Peraturan Pemerintah Pengganti } \\
\text { Undang-Undang Nomor } 2 \text { Tahun } 2008 \text { tentang } \\
\text { Perubahan Kedua atas Undang-Undang Nomor } \\
23 \text { Tahun } 1999 \text { tentang Bank Indonesia menjadi } \\
\text { Undang-Undang }\end{array}$ \\
\hline 3 & Undang-Undang Nomor 17 Tahun 2003 & Keuangan Negara \\
\hline 4 & Undang-Undang Nomor 1 Tahun 2004 & Perbendaharaan Negara \\
\hline 5 & $\begin{array}{l}\text { Undang-Undang Nomor } 24 \text { Tahun } 2004 \\
\text { tentang Lembaga Penjamin Simpanan } \\
\text { sebagaimana telah diubah dengan Undang- } \\
\text { Undang Nomor } 7 \text { Tahun } 2009 \text { tentang } \\
\text { Penetapan Peraturan Pemerintah Pengganti } \\
\text { Undang- Undang Nomor } 3 \text { Tahun } 2008 \\
\text { tentang Perubahan atas Undang-Undang } \\
\text { Nomor } 24 \text { Tahun } 2004 \text { Menjadi Undang- } \\
\text { Undang }\end{array}$ & Lembaga Penjamin Simpanan \\
\hline 6. & Undang-Undang Nomor 33 Tahun 2004 & $\begin{array}{l}\text { Perimbangan Keuangan Antara Pemerintah Pusat } \\
\text { dan Pemerintahan Daerah }\end{array}$ \\
\hline 7. & Undang-Undang Nomor 36 Tahun 2009 & Kesehatan \\
\hline 8. & Undang-Undang Nomor 6 Tahun 2014 & Desa \\
\hline 9. & $\begin{array}{l}\text { Undang-Undang Nomor } 23 \text { Tahun } 2014 \\
\text { tentang Pemerintahan Daerah sebagaimana } \\
\text { telah beberapa kali diubah terakhir dengan } \\
\text { Undang-Undang Nomor } 9 \text { Tahun } 2015\end{array}$ & $\begin{array}{l}\text { Perubahan Kedua atas Undang-Undang Nomor } \\
23 \text { Tahun } 2014 \text { tentang Pemerintahan Daerah }\end{array}$ \\
\hline 10 & Undang-Undang Nomor 9 Tahun 2016 & $\begin{array}{l}\text { Pencegahan dan Penanganan Krisis Sistem } \\
\text { Keuangan }\end{array}$ \\
\hline 11. & $\begin{array}{l}\text { Undang-Undang Negara Republik } \\
\text { Indonesia Nomor } 6 \text { Tahun } 2018\end{array}$ & Kekarantinaan Kesehatan \\
\hline 12. & Undang-Undang Nomor 20 Tahun 2019 & $\begin{array}{l}\text { Anggaran Pendapatan dan Belanja Negara Tahun } \\
\text { Anggaran } 2020\end{array}$ \\
\hline
\end{tabular}

Ketentuan lain dalam Perppu Nomor 1 Tahun 2020 di satu sisi yang menentukan, bahwa biaya yang dikeluarkan dalam rangka pelaksanaan kebijakan pendapatan dan belanja negara, pembiayaan, stabilitas sistem keuangan, keuangan daerah, bidang perpajakan, dan program pemulihan ekonomi nasional merupakan bagian dari biaya ekonomi dalam rangka penyelamatan perekonomian terhadap potensi krisis, dan bukan merupakan sebuah kerugian negara. $^{21}$ Potensi besar penyalahgunaan kewenangan ${ }^{22}$ bagi keuntungan pribadi dan kelompok dengan mengatasnamakan

21 Pasal 27 Ayat (1) Perppu Nomor 1 Tahun 2020.

22 Kekuasaan oleh Lord Acton cenderung korup, namun kekuasaan yang absolut sudah pasti korup (power tends to corrupt, but absolute power corrupt absolutely). lihat Syaiful Bakhri, Pergumulan Filsafat, Sejarah dan Negara Hukum, (Depok: RajaGrafindo Persada, 2018), Hlm. 189-191. 
kebijakan penanganan COVID-19, dan menjaga stabilitas keuangan negara dapat saja terjadi dalam hal ini. Ketentuan ini menjadi a contrario dengan legalitas atau keabsahan (validitas), dan menderivasi ketentuan pengaturan sebagaimana diatur dalam undangundang yang berkenaan pemberantasan tindakan pidana korupsi. Ketentuan di dalam Perppu Nomor 1 Tahun 2020 ini sudah dari awal secara a priori, bahwa tidak ada kerugian negara, dan kalaupun ada, maka tidak dapat dimasukkan sebagai pengertian merugikan keuangan negara. ${ }^{23}$

Anggota KSSK, Sekretaris KSSK, anggota sekretariat KSSK, dan pejabat atau pegawai Kementerian Keuangan, Bank Indonesia, Otoritas Jasa Keuangan, serta Lembaga Penjamin Simpanan, dan pejabat lainnya, yang berkaitan dengan pelaksanaan Perppu ini, selain itu, untuk menjaga stabilitas keuangan negara, tidak dapat dituntut baik secara perdata maupun pidana jika dalam melaksanakan tugas didasarkan pada iktikad baik dan sesuai dengan ketentuan peraturan perundang-undangan. ${ }^{24}$ Menguji itikad baik (te goeder trouw), dan kesesuaiannya dengan peraturan perundang-undangan ${ }^{25}$ yang ada sebagaimana ketentuan ayat ini, tentu saja tidak dapat dikalim secara sepihak oleh pemerintah, bahwa Anggota KSSK, Sekretaris
KSSK, anggota sekretariat KSSK, dan pejabat atau pegawai Kementerian Keuangan, Bank Indonesia, Otoritas Jasa Keuangan, serta Lembaga Penjamin Simpanan, dan pejabat lainnya, akan selalu mempunyai itikad baik, dan segala tindakannya pasti sesuai dengan peraturan yang berlaku. Ketentuan ini sudah dari awal sudah a priori, dan menegasikan (kontra produktif) dengan kewenangan lembaga negara lainnya untuk menguji tindakan pemerintahan. Insrumen dan kewenangan untuk menguji itikad baik dan kesesuaiannya dengan peraturan perundangundangan yang berlaku, sesuai dengan hukum positif yang berlaku tentu saja harus diuji oleh lembaga negara yang independen. Lembaga negara yang memang mempunyai kewenangan untuk itu, yaitu lembaga peradilan (yudikatif), atas pelaksanaan kebijakan dari Perppu tersebut oleh pemerintah.

Selain itu, pemerintah pada waktu mengeluarkan Perpuu Nomor 1 Tahun 2020 menyatakan bahwa semua tindakan pejabat administrasi negara, termasuk keputusan yang diambil berdasarkan Peraturan Pemerintah Pengganti Undang-Undang ini bukan merupakan objek gugatan yang dapat diajukan kepada Peradilan Tata Usaha Negara, tidak memperhatikan Undang-Undang Nomor 51 Tahun 2009, atau setidaknya terdapat kelalaian

23 Pasal 2 Ayat (1), Pasal 3, dan 4 Undang-Undang Nomor 31 Tahun 1999 tentang Pemberantasan Tindak Pidana Korupsi (Lembaran Negara Republik Indonesia Tahun 1999 Nomor 140, Tambahan Lembaran Negara Republik Indonesia Nomor 3874).

24 Pasal 27 Ayat (2) Perppu Nomor 1 Tahun 2020.

25 Pegawai negara dan kotapraja sebagai badan hukum oleh Muchsan bertanggungjawab atas tindakan mereka sendiri, dan dapat dipaksa membayar ganti kerugian bagi jiwa dan harta atas tindakan yang defective. Lihat Muchsan, Peradilan Administrasi Negara, (Yogyakarta: Liberty, 1981), Hlm. 31-33. 
memperhatikan peraturan ini. ${ }^{26}$ UndangUndang Nomor 51 Tahun 2009 sendiri sudah menyatakan dengan tegas bahwasanya setiap keputusan pemerintahan yang diambil dalam keadaan kedaruratan kesehatan masyarakat, dan dalam rangka stabilitas keuangan negara sebagaimana ketentuan di dalam undangundang yang berkenaan dengan peradilan tata usaha negara, memang tidak dapat digugat di peradilan administrasi negara. Pengadilan tidak berwenang memeriksa, memutus, dan menyelesaikan sengketa tata usaha negara tertentu dalam hal keputusan yang disengketakan itu dikeluarkan, pertama, dalam waktu perang, keadaan bahaya, keadaan bencana alam, atau keadaan luar biasa yang membahayakan, berdasarkan peraturan perundang-undangan yang berlaku, dan ke dua, dalam keadaan mendesak untuk kepentingan umum berdasarkan peraturan perundang-undangan yang berlaku.

b. Peraturan Pemerintah (PP) dan Keputusan Presiden (Keppres)

Peraturan Pemerintah (PP) yang dikeluarkan oleh pemerintah dalam rangka PSBB dalam alasan mengingatnya merujuk secara yuridis kepada tiga undang-undang sekaligus $^{27}$, namun apabila ditelusuri pasal demi pasal, tidak sekalipun dua undang- undang lainnya dijadikan sebagai dasar yuridis. Alasan mengingat sebagai pertimbangan hukum PP ini hanya secara sepihak merujuk pada Undang-Undang Nomor 6 Tahun 2018 tentang Kekarantinaan Kesehatan. Peraturan Pemerintah Nomor 21 Tahun 2020 ini juga menentukan, bahwa PSBB diusulkan oleh gubernur/bupati/walikota kepada menteri yang menyelenggarakan urusan pemerintahan di bidang kesehatan, sekaligus menetapkan PSBB dengan memperhatikan pertimbangan Ketua Pelaksana Gugus Tugas Percepatan Penanganan Corona Virus Disease 2019 (COVID-19), Ketua Pelaksana Gugus Tugas Percepatan Penanganan Corona Virus Disease 2019 (COVID-19) dapat mengusulkan kepada menteri yang menyelenggarakan urusan pemerintahan di bidang kesehatan untuk menetapkan Pembatasan Sosial Berskala Besar di wilayah tertentu, dan apabila disetujui, kepala daerah di wilayah tertentu wajib melaksanakan $\mathrm{PSBB}^{28}$. Peraturan Pemerintah Nomor 21 Tahun 2020 ini justru tidak dijadikan alasan mengingat semua Keppres yang dibuat oleh presiden, dengan kata lain, tidak satupun Keppres dalam rangka penanganan COVID-19 yang menjadikan Peraturan Pemerintah Nomor 21 Tahun 2020 sebagai landasan yuridis berlakunya. ${ }^{29}$

26 Pasal 27 Ayat (3) Perppu Nomor 1 Tahun 2020.

27 Undang-Undang Nomor 4 Tahun 1984 tentang Wabah Penyakit Menular (Lembaran Negara Republik Indonesia Tahun 1984 Nomor 20, Tambahan Lembaran Negara Republik Indonesia Nomor 3273), Undang-Undang Nomor 24 Tahun 2007 tentang Penanggulangan Bencana (Lembaran Negara Republik Indonesia Tahun 2007 Nomor 66, Tambahan Lembaran Negara Republik Indonesia Nomor 4723), dan Undang-Undang Nomor 6 Tahun 2018 tentang Kekarantinaan Kesehatan (Lembaran Negara Republik Indonesia Tahun 2018 Nomor 128, Tambahan Lembaran Negara Republik Indonesia Nomor 6236). Bandingkan dengan alasan mengingat di dalam Perppu Nomor 1 Tahun 2020.

28 Pasal 6 (1), (2), (3), dan (4) PP Nomor 21 Tahun 2020.

29 Keppres Nomor 7 Tahun 2020; Keppres Nomor 9 Tahun 2020; Keppres Nomor 11 Tahun 2020; Keppres Nomor 12 Tahun 2020. 
Keputusan Presiden yang lainnya, di lain sisi, juga menentukannya sebagai bencana non-alam yang disebabkan oleh penyebaran COVID-19, yang telah berdampak pada meningkatnya jumlah korban dan kerugian harta benda, meluasnya cakupan wilayah yang terkena bencana, serta menimbulkan implikasi pada aspek sosial ekonomi yang luas di Indonesia. Keputusan presiden ini menetapkan, pertama, bencana non-alam yang diakibatkan oleh penyebaran COVID19, sebagai bencana nasional, ke dua, penanggulangan bencana nasional yang diakibatkan oleh penyebaran COVID-19, dilaksanakan oleh Gugus Tugas Percepatan Penanganan Corona Virus Disease 2019 (COVID-19) ${ }^{30}$.

Membaca raison d' etre dari kedua Keppres Nomor 11 Tahun 2020 dan Keppres Nomor 12 Tahun 2020 dari segi materi normanya adalah sama, walaupun dengan materi penetapan yang berbeda. Keppres Nomor 11 Tahun 2020 menetapkan keadaan penyebaran COVID-19 sebagai kedaruratan kesehatan masyarakat, sedangkan Keppres Nomor 12 Tahun 2020 membaca penyebaran COVID-19 ini sebagai bencana nasional dan perihal penanggulangannya oleh suatu gugus tugas. Dampak dari penyebaran COVID-19 berdasarkan kedua Keppres inipun tidak ada perbedaan yang mendasar. Keppres Nomor 11 Tahun 2020 menentukan jumlah kasus atau kematian yang telah meningkat, dan meluas lintas wilayah dan lintas negara dan berdampak pada aspek politik, ekonomi, sosial, budaya, pertahanan dan keamanan, serta kesejahteraan masyarakat di Indonesia. Keppres Nomor 12 Tahun 2020 juga tidak berbeda jauh, melihat dampaknya pada meningkatnya jumlah korban dan kerugian harta benda, meluasnya cakupan wilayah yang terkena bencana, serta menimbulkan implikasi pada aspek sosial ekonomi yang luas di Indonesia.

Keppres Nomor 11 Tahun 2020, walaupun demikian, merupakan peraturan organik (pelaksanaa) dari Undang-Undang Nomor 6 Tahun 2018 tentang Kekarantinaan Kesehatan, sedangkan Keppres Nomor 12 Tahun 2020 adalah peraturan organik dari Undang-Undang Nomor 4 Tahun 1984 tentang Wabah Penyakit Menular, Undang-Undang Nomor 24 Tahun 2007 tentang Penanggulangan Bencana, dan Keppres Nomor 7 Tahun 2020 sebagaimana telah diubah dengan Keppres Nomor 9 Tahun 2020. Peraturan perundang-undangan yang dibuat pasca munculnya pandemi COVID-19 pada pokoknya adalah upaya penanganan pemerintah untuk itu, selain untuk menjaga stabilitas keuangan negara. Inkonsistensi hierarki peraturan perundang-undangan dalam penanganan COVID-19 dapat dilihat dari obyek/subyek hukum, dan landasan yuridis yang menjadi dasarnya, sebagaimana tabel di bawah ini: 
Tabel 2. Obyek/Subyek Hukum, dan Landasan Yuridis Pengaturan dalam Penanganan COVID-19, berdasarkan tanggal keluar.

\begin{tabular}{|c|c|c|}
\hline Produk Hukum & Obyek dan Subyek Pengaturan & Alasan Mengingat \\
\hline $\begin{array}{l}\text { Keppres Nomor } 7 \\
\text { Tahun } 2020 \\
13 \text { Maret } 2020\end{array}$ & $\begin{array}{l}\text { Gugus Tugas Percepatan } \\
\text { Penanganan Corona Virus Disease } \\
\text { (COVID-19) }\end{array}$ & $\begin{array}{l}\text { a. Pasal } 4 \text { Ayat (1) UUD NRI 1945; } \\
\text { b. UU Nomor } 4 \text { Tahun 1984; } \\
\text { c. UU Nomor } 24 \text { Tahun 2007; } \\
\text { d. UU Nomor } 36 \text { Tahun 2009; } \\
\text { e. UU Nomor } 6 \text { Tahun 2018; } \\
\text { f. Perpres Nomor } 17 \text { Tahun } 2018\end{array}$ \\
\hline $\begin{array}{l}\text { Keppres Nomor } 9 \\
\text { Tahun } 2020 \\
20 \text { Maret } 2020\end{array}$ & $\begin{array}{l}\text { a. Perubahan Keppres Nomor } 7 \\
\text { Tahun } 2020 \\
\text { b. Gugus Tugas Percepatan } \\
\text { Penanganan Corona Virus } \\
\text { Disease (COVID-19) }\end{array}$ & $\begin{array}{l}\text { a. Pasal } 4 \text { Ayat (1) UUD NRI 1945; } \\
\text { b. UU Nomor } 4 \text { Tahun 1984; } \\
\text { c. UU Nomor } 24 \text { Tahun 2007; } \\
\text { d. UU Nomor } 36 \text { Tahun 2009; } \\
\text { e. UU Nomor } 6 \text { Tahun 2018; } \\
\text { f. PP Nomor } 21 \text { Tahun 2008; } \\
\text { g. PP Nomor } 22 \text { Tahun 2008; } \\
\text { h. PP Nomor } 12 \text { Tahun 2017; } \\
\text { i. PP Nomor } 12 \text { Tahun 2019; } \\
\text { j. Perpres Nomor } 16 \text { Tahun 2018; } \\
\text { k. Perpres Nomor } 17 \text { Tahun 2018 }\end{array}$ \\
\hline $\begin{array}{l}\text { Perppu Nomor } 1 \\
\text { Tahun } 2020 \\
31 \text { Maret } 2020\end{array}$ & $\begin{array}{l}\text { Biaya penanganan COVID-19 } \\
\text { Perekonomian nasional dan/atau } \\
\text { stabilitas sistem keuangan }\end{array}$ & Pasal 22 ayat (1) UUD NRI 1945 \\
\hline $\begin{array}{l}\text { PP Nomor } 21 \text { Tahun } \\
2020 \\
31 \text { Maret } 2020\end{array}$ & $\begin{array}{l}\text { Pembatasan Sosial Berskala Besar } \\
\text { (PSBB) dalam rangka percepatan } \\
\text { penanganan Corona Virus Disease } \\
2019 \text { (COVID-19) }\end{array}$ & $\begin{array}{l}\text { a. Pasal } 5 \text { ayat (2) UUD NRI 45; } \\
\text { b. UU Nomor } 4 \text { Tahun } 1984 \text {; } \\
\text { c. UU Nomor } 24 \text { Tahun } 2007 \text {; } \\
\text { d. UU Nomor } 6 \text { Tahun } 2018\end{array}$ \\
\hline $\begin{array}{l}\text { Keppres Nomor } 11 \\
\text { Tahun 2020 } \\
31 \text { Maret } 2020\end{array}$ & $\begin{array}{l}\text { Kedaruratan Kesehatan Masyarakat } \\
\text { Corona Virus Disease } 2019 \\
\text { (COVID-19) }\end{array}$ & $\begin{array}{l}\text { a. Pasal } 4 \text { Ayat (1) UUD NRI 1945; } \\
\text { b. UU Nomor } 6 \text { tahun } 2018\end{array}$ \\
\hline $\begin{array}{l}\text { Keppres Nomor } 12 \\
\text { Tahun } 2020 \\
13 \text { April } 2020\end{array}$ & $\begin{array}{l}\text { a. Penetapan bencana nasiona01 } \\
\text { yang diakibatkan oleh } \\
\text { penyebaran Corona Virus } \\
\text { Disease } 2019 \text { (COVID-19) } \\
\text { b. Gugus Tugas Percepatan } \\
\text { Penanganan Corona Virus } \\
\text { Disease } 2019 \text { (COVID-19) }\end{array}$ & $\begin{array}{l}\text { a. Pasal } 4 \text { ayat (1) UUD NRI } 45 \text {; } \\
\text { b. UU Nomor } 4 \text { Tahun } 1984 ; \\
\text { c. UU Nomor } 24 \text { Tahun } 2007 \text {; } \\
\text { d. Keppres Nomor } 9 \text { Tahun } 2020\end{array}$ \\
\hline
\end{tabular}

Sumber: Diolah dari regulasi yang ada, Maret - Desember 2020

Catatan:

- Perubahan Keppres Nomor 7 Tahun 2020 menjadi Keppres Nomor 9 Tahun 2020 terdapat penambahan di alasan mengingatnya, yaitu PP Nomor 21 tahun 2008, PP Nomor 22 Tahun 2008, PP Nomor 12 Tahun 2017, PP Nomor 12 Tahun 2019, dan Perpres Nomor 16 Tahun 2018.

- PP Nomor 21 Tahun 2020 tidak mencantukan Perppu Nomor 1 Tahun 2020 dalam alasan mengingatnya.
- Keppres Nomor 11 Tahun 2020 tidak mencantumkan PP Nomor 21 Tahun 2020 dalam alasan mengingatnya, walaupun mencantumkan UU Nomor 6 Tahun 2018.

- Keppres Nomor 12 Tahun 2020 tidak mencantumkan UU Nomor 6 Tahun 2018 dan PP Nomor 21 Tahun 2020 dalam alasan mengingatnya, justru mencantumkan Keppres Nomor 9 Tahun 2020. 
Apabila mencermati Pasal 1 angka 11 Undang-Undang Nomor 6 Tahun 2018, jo. Pasal 1 PP Nomor 21 Tahun 2020, kemudian dibandingkan dengan Pasal 1 angka 8, 9, dan 10 dalam Undang-Undang Nomor 6 Tahun 2018, antara pengertian membatasi aktifitas orang dalam PSBB dengan membatasi orang dalam suatu area tertentu untuk tidak meninggalkan tempat yang dibatasi tersebut, dan melarang orang lain di luar karantina untuk masuk ke dalam areakarantina mengandung konsekuensi ekonomi di dalamnya. Pembatasan aktifitas berarti masyarakat masih dapat melakukan kegiatan atau aktifitas sosial ekonominya, walaupun secara terbatas berdasarkan pada ketentuan PSBB.

Masyarakat dengan demikian masih dapat memenuhi kebutuhan sosial-ekonominya secara mandiri dalam penerapan PSBB, sehingga negara dalam hal ini, terlepas dari tanggungjawab hukum, kewajiban untuk menanggung konsekuensi ekonomi di dalamnya. Karantina memiliki akibat hukum ${ }^{31}$ yang berbeda, yang dibatasi adalah orangnya, sehingga berakibat pada segala aktifitas sosialekonominya turut terganggu. Aktifitas sosialekonomi dalam karantina tidak ada, oleh karena setiap orang ditempatkan pada area tertentu, misalnya rumah, wilayah, atau rumah sakit, negara dalam hal ini, dengan penerapan kebijakan karantina menanggung akibat hukum, kewajiban berupa tanggungjawab untuk memenuhi segala kebutuhan sandang dan pangan orang-orang yang dikarantina. ${ }^{32}$

Perbedaan tanggungjawab hukum negara atas penerapan kekarantinaan kesehatan melalui PSBB terbatas pada pengaturan dan administrasi negara, memanajemen agar interaksi sosial-ekonomi sedemikian rupa dibatasi. Pembatasan sosial dalam skalanya meliputi satu wilayah tertentu ini misalnya, penerapan jarak komunikasi seseorang dengan orang lainnya minimal satu sampe dengan dua meter. Jarak fisik ini berguna agar supaya penularan virus COVID-19 tidak terjadi di antara orang-orang yang sedang melakukan interaksi sosial-ekonominya (pembatasan jarak). Sarana dan prasarana privat maupun publik juga diatur sedemikian rupa agar masyarakat dalam berinteraksi diatur jaraknya, atau mencegah kerumunan (massa) berkumpul secara berlebihan. Interaksi sosial dalam PSBB ini juga dihimbau dengan jalan penggunaan masker dalam setiap aktifitas orang per orang.

Karantina baik rumah, rumah sakit, dan wilayah, lalu lintas pergerakan orang untuk keluar masuk wilayah karantina tidak dimungkinkan. Pembatasan sosial dalamPSBB sendiri tidak menjangkau untuk membatasi lalu lintas orang untuk keluar dan masuk pada wilayah pintu masuk atau keluar wilayah

31 Ketentuan final dalam AROB di Belanda tidak dikenal istilah akibat hukum, tidak ada ketentuan yang menyatakan suatu keputusan administrasi negara belum final, atau definitif. Setiap keputusan administrasi negara yang dikeluarkan harus dianggap sudah final, dan definitif, sehingga dianggap telah mempunyai akibat hukum, S. F. Marbun, dan Mahfud MD, Pokok-pokok Hukum Administrasi Negara, (Yogyakarta: Liberty), 1987, Hlm. 90.

32 Pasal 55, 52, dan 58, dan bandingkan dengan Pasal 59 dalam Undang-Undang Nomor 6 Tahun 2018. 
pembatasan. Setiap orang, baik yang berasal dari wilayah pembatasan (PSBB), maupun orang-orang yang berasal dari luar wilayah pembatasan masih dimungkinkan untuk keluar masuk. Sifat manajemen prosedur dan mekanisme PSBB terkait dengan pintu masuk dan keluar pergerakan masyarakat umum terkait hanya berupa himbauan. Strateginya dalam rangka pembatasan aktifitas orang, baik yang berasal dalam wilayah pembatasan maupun yang dari luar bisa saja dilakukan dengan pembatasan penggunaan transportasi publik, dan privat.

Tanggungjawab hukum negara dalam karantina tidak terbatas pada pengaturan dan administrasi negara atas memanajemen agar interaksi sosial-ekonomi sedemikian rupa dibatasi. Negara selain melaksanakan managemen pembatasan dalam karantina, juga dapat menggerakkan perangkat-perangkat institusionalnya dalam rangka penegakan hukum, seperti satuan polisi pamong praja (Satpol PP), polisi, dan aparat sipil negara yang lainnya ${ }^{33}$ yang terkait dengan penerapan karantina. Penegakan hukum dalam kerangka karantina atas area tertentu ini mempunyai akibat hukum publik dalam hukum pidana. ${ }^{34}$

Karantina memiliki karakter hukum dalam penerapan sanksi ${ }^{35}$ yang berbeda dengan PSBB, aparat penegak hukum dengan penetapan karantina dapat menggunakan instrumen hukum pidana untuk melakukan penyelidikan dan penyidikan yang apabila terbukti melanggar penetapan karantina akan dikenakan sanksi denda atau penjara. Sanksi hukum dalam PSBB sebagaimana UU Nomor 6 Tahun 2018 juga tidak memiliki kejelasan sanksi yang dapat digunakan oleh aparat penegak ${ }^{36}$ hukum seperti polisi, dan petugas kesehatan (PPNS, penyidik pegawai negeri sipil) yang diberi kewenangan untuk menegakkan PSBB, sifatnya terbatas pada himbauan kepada masyarakat.

Pilihan pemerintah dengan penetapan PSBB melalui peraturan pemerintah (PP) dengan jalan membatasi aktifitas atau kegiatan masyarakat sebagaimana ditentukan dalam UU Nomor 6 Tahun 2018, dalam terminologi hukum positif di Indonesia, pemerintah tidak memiliki kewajiban untuk menyediakan kebutuhan sehari-hari masyarakat yang diambil dari anggaran negara yang disediakan untuk itu. PSBB hanya sekedar membatasi tanpa kewajiban tanggungjawab logistik bagi kebutuhan masyarakat, berbeda apabila pemerintah mengambil pilihan untuk melakukan karantina wilayah, maka pemerintah berkewajiban menanggung segala kebutuhan hidup sehari-hari masyarakat yang dikarantina, yang disediakan dari anggaran

33 S. Prajudi Atmosudirjo, Hukum Administrasi Negara, (Jakarta: Ghalia Indonesia), 1988,Hlm. 11-12

34 Pasal 90, 91, 92, 93, dan 94 Undang-Undang Nomor 6 Tahun 2018.

35 A. D. Belinfante, dan Boerhanoeddin Soetan Batoeah, Pokok-Pokok Hukum Tata Usaha Negara, (Jakarta: Binacipta), 1983, Hlm. 99. Lihat juga Irvan Mawardi, Dinamika Sengketa Hukum Administrasi di Pemilukada; Mewujudkan Electoral Justice dalam Kerangka Negara Hukum Demokratis, (Yogyakarta: Rangkang Education), 2014, Hlm. 140.

36 Pasal 84 Undang-Undang Nomor 6 Tahun 2018 tentang Kekarantinaan Kesehatan. 
negara. Logistik PSBB bagi masyarakat sifatnya tidak wajib, sekedar kebijakan bebas pemerintah, memberi bantuan terbatas sesuai dengan kemampuan pemerintah. PSBB melalui PP Nomor 21 Tahun 2020 ini berbanding terbalik dengan ketentuan di dalam Perppu Nomor 1 Tahun 2020, yang mengatur biaya penanganan COVID19, dan stabilisasi keuangan negara. Pada titik kesimpulan, kebijakan yang diambil pemerintah melalui PSBB cenderung lebih mementingkan aspek perekonomian agar tetap berjalan sebagaimana biasanya dibandingkan dengan kebijakan yang lebih berorientasi pada pembatasan ruang gerak dari sebaran COVID-19 itu sendiri.

\section{B. Kebijakan Penanganan COVID-19 dalam Perspektif Aliran Sociological Jurisprudence}

Mendalilkan pemikiran sociological jurisprudence Roscoe Pound, hukum seyogyanya diinterpretasikan sebagai solusi berbasis kehendak atau keinginan masyarakat terhadap fakta-fakta realitas sosial yang ada, sehingga hukum kemudian dapat diimplementasikan dengan baik kepada publik. ${ }^{37}$ Hukum dalam konsepsi Roscoe Pound bukanlah hukum yang bersifat mekanistis atau dalam arti sederhana hukum tidaklah bekerja dengan keteraturan secara rigid, ${ }^{38}$ hukum harus tumbuh dan berkembang sejalan dengan kebutuhan masyarakat. Bertalian dengan pandangan Pound eksekusi kebijakan termasuk produk hukum didalamnya terhadap persoalan kesenjangan sosial hanya didasarkan pada kehendak dan penilaian dari perspektif negara semata. ${ }^{39}$ Sociological jurisprudence memandang bahwa probematika sosial harus diselesaikan sesuai dengan kebutuhan yang bersumber dari aspirasi masyarakat secara utuh dan bukan secara individual orang per orang ${ }^{40}$ di mana kolaborasi konstruksi hukum yang indah sangat diperlukan ibarat sebuah "“team-work" between jurisprudence and the other social science". ${ }^{41}$

Melihat kritisi kebijakan penanganan COVID-19 sebagaimana telah diulas di atas, maka dalam perspektif sociological jurisprudence kebijakan yang diambil oleh pemerintah setidaknya bersandarkan kepada empat poin mendasar. Pertama, hukum yang hendak dirumuskan, sebelumnya harus didasarkan pada sebuah kajian mendalam atau riset terarah bertalian dengan potensi dampak sosial sebagai respon dari publik. Apabila dihubungan dengan kebijakan penanganan pandemi COVID-19, kebijakan yang diambil melalui PSBB, nampaknya tidak didasarkan

37 Roscoe Pound, "The Scope and Purpose of Sociological Jurisprudence III", Harvard Law Review, Vol. 25, No. 6, (Apr., 1912), p. 513. Lihat juga B. Tamanaha, "Sociological Jurisprudence Past and Present", Law \& Social Inquiry, Vol. 45, No 2 (2020), pp.493-520.

38 Roscoe Pound, "Mechanical Jurisprudence", Columbia Law Review, Vol. 8, Issue 8, (1908), pp. 605-623.

39 Roscoe Pound, "Law in Books and Law in Action", American Law Review Vol. 44, Issue 1, (January-February 1910), pp. 26-27.

40 Roscoe Pound, "The Need of a Sociological Jurisprudence", Crime \& Delinquency, Volume 10, Issue 4, (October 1, 1964) pp. 385-397

41 Roscoe Pound, "The Scope and Purpose of Sociological Jurisprudence III", op . cit, p.510 
kepada kajian riset yang matang, sehingga alih-alih memberikan kebijakan yang longgar dan tidak rigid, namun melalui kebijakan pembatasan kegiatan ekonomi seperti menutup pabrik, pembatasan jam operasional kantor/supermarket/mall, dan pembatasan transportasi publik akan berakibat pemutusan hubungan kerja secara masif, dan pada satu sisi yang sama tidak menutup kemungkinan meningkatnya jumlah masyarakat yang terinfeksi virus COVID-19. Dalam pemikiran sociological jurisprudence, hukum merupakan sarana (tools) untuk merekayasa masyarakat, ${ }^{42}$ sehingga produk hukum ideal sejatinya bersendikan pada kemauan publik dalam menjaga ritme kehidupan melalui kegiatan ekonomi yang selaras dengan tujuan yang lebih besar yaitu pencegahan penularan COVID-19. Terkait hal ini, produk yang hukum yang tersedia sebaiknya memuat langkah riil yang ditempuh berbasis kegiatan kemasyarakatan antara lain dengan memberikan literasi yang cukup dan update terkait dengan virus COVID-19, di mana hal ini dapat dilakukan melalui optimalisasi pemberdayaan RT (rukun tetangga) dan RW (rukun warga) seperti misalnya penyediaan tempat cuci tangan di depan rumah, kontinuitas kegiatan penyemprotan disinfektan secara mandiri, serta penguatan mekanisme pengawasan oleh ketua RT dan ketua RW di lingkungan masing-masing.
Melalui insentif pemberian pulsa dan data dari anggaran kabupaten, ketua RT dan ketua RW secara berjenjang kemudian memberikan laporan periodik untuk disampaikan kepada gugus tugas COVID-19 di masing-masing kecamatan, sehingga penanganan COVID-19 dapat termonitor dengan baik.

Poin kedua, aliran sociological jurisprudence menghendaki bahwa perumusan regulasi atau produk hukum terkait kebijakan penanganan COVID-19 harus diselaraskan dengan aspek keilmuan yang lain, seperti aspek psikologi, sosial, kesehatan, dan ekonomi. ${ }^{43}$ Mencermati produk hukum sebagaimana diulas di atas, dapat diberikan komentar bahwasanya pembentukan Perppu, PP, dan Keppres telah nyata disusun tanpa mempertimbangkan aspek-aspek terkait lain, mengingat durasi penyusunan ketiga produk hukum sampai pengundangan hanya dibentuk dalam waktu yang singkat. Kondisi darurat atas sebaran virus COVID-19 tidak dapat dijadikan alasan (reasoning) untuk meniadakan pertimbangan aspek psikologis, aspek sosial, aspek tenaga kesehatan yang tersedia, dan aspek pendidikan di dalam mengkonstruksikan produk hukum mengingat bahwasanya penyusunan produk hukum yang singkat belum tentu akan berjalan efektif ketika diterapkan kepada masyarakat. Poin ketiga, aliran sociological jurisprudence berkeinginan agar tahap implementasi produk

42 Roscoe Pound, Social Control Through Law, (New Brunswick: Transaction Publishers, 1997), pp.xx, 138. Lihat juga Vytautas Šlapkauskas, "The Significance of the Sociological Approach to Law for the Development of Jurisprudence", Societal Studies, Vol. 4, No. 8, (2010), pp. 167-181.

43 Roscoe Pound, "The Scope and Purpose of Sociological Jurisprudence III”, op. cit, p. 514 
hukum sebagai dasar kebijakan penanganan COVID-19 seyogyanya berjalan dengan efektif. ${ }^{44}$ Makna efektif di sini kemudian dapat ditafsirkan bahwa pemerintah seyogyanya tidak perlu untuk membuat Perppu, PP, dan Keppres yang baru, namun (bisa saja) cukup menggunakan produk hukum yang sudah tersedia. Penyusunan norma hukum yang baru terkait penanangan Coivd-19 adakalanya disusun dengan tidak cermat dan belum tentu menghasilkan solusi yang efektif berbasis kebutuhan masyarakat. Sebagaimana telah dijelaskan sebelumnya bahwa kebijakan penanganan COVID-19 sejatinya telah dirumuskan secara gamblang di dalam Undang-Undang Nomor 6 Tahun 2018 tentang Kekarantinaan Kesehatan. Pilihan karantina yang kemudian menjadi beban berat bagi anggaran pemerintah dapat dikomunikasikan dengan jujur kepada publik. Masyarakat Indonesia yang terkenal dengan guyub rukun dan gotong royong dipastikan akan menerima dengan lapang dada, andaikata pemerintah bersikap jujur dalam hal ketidamampuan pemberian logisitik sebagai konsekuensi penerapan pasal-pasal di dalam UU Nomor 6 Tahun 2018, maka solusi-solusi kemasyarakatan berbasis prinsip gotong royong, tepo sliro akan muncul dengan sendirinya guna membatasi ruang gerak penyebaran virus COVID-19. Dalam rangka merumuskan kebijakan penanganan COVID-19 supaya berjalan dengan baik, maka dukungan kebijakan dari masing-masing kementrianjuga diharapkan salingmenguatkan dan terkoordinasi dengan baik. Salah satu contoh kebijakan yang kontraproduktif adalah kebijakan melepaskan sejumlah 37 ribu narapidana (napi) se-Indonesia dengan dalih nilai kemanusiaan dan mencegah penyebaran COVID-19 melalui Peraturan Menteri Hukum dan Hak Asasi Manusia Nomor 10 Tahun 2020 tentang Asimilasi. Dalam perspektif sociological jurisprudence ${ }^{45}$, kebijakan yang ditempuh ini sangat tidak diinginkan oleh publik di tengah masa pandemi, bahkan tugas kepolisian dalam kerangka mendukung kebijakan PSBB justru akan tersita oleh ulah narapidana yang melakukan kejahatan kembali sesaat setelah dibebaskan. Andaikata berbasis kepada nalar kebijakan yang rasional, kebijakan asimilasi di tengah masa pandemi seyogyanya dapat dialihkan menuju kebijakan yang produktif dalam rangka mendukung pencegahan penyebaran virus COVID-19, antara lain dengan memberdayakan para napi untuk membuat masker atau alat pelindung diri bagi tenaga medis.

Poin keempat, sociological jurisprudence merekomendasikan dengan tegas bahwa kebijakan penanangan COVID-19 harus ditujukan kepada hakikat dasar persoalan apa

44 Ibid. Lihat juga James A. Gardner, "The Sociological Jurisprudence of Roscoe Pound (Part I)", Vill. L. Rev., Vol. 7, Issue 1 (1961), pp. 1-26

45 Louis H. Masotti, "Theory and Application of Roscoe Pound's Sociological Jurisprudence: Crime Prevention or Control?", U. Mich. J. L. REFORM, Vol. 2 (1969), pp. 431-449. Lihat juga Kathryn Nowotny, Zinzi Bailey, Marisa Omori, and Lauren Brinkley-Rubinstein, "COVID-19 Exposes Need for Progressive Criminal Justice Reform", Am. J. Public Health., Vol. 10 No. 7, (2020), pp. 967-968 
yang hendak diselesaikan. ${ }^{46}$ Mengingat bahwa tujuan utama produk hukum adalah mengatasi persoalan fundamental yang ada ditengah masyarakat, dalam konteks membatasi ruang persebaran virusCOVID-19, maka seyogyanya kebijakan penanganan pemerintah difokuskan kepada pembatasan ruang gerak virus COVID-19 itu sendiri dan bukan kebijakan lain. Tidak menampik kemungkinan dalam perumusan kebijakan akan bersinggungan dengan aspek atau bidang yang lain, sehingga penyusunan produk hukum pemerintah dalam pandangan sociological jurisprudence wajib disusun secara cermat dan penuh kehatihatian, pertimbangan yang matang, serta rasional berbasiskan aspirasi publik sehingga apa yang menjadi persoalan utama ditengah masyarakat dapat diterselesaikan dengan baik dengan meminimalisir potensi dampak buruk yang justru akan menimpa kepada publik. ${ }^{47}$

\section{Simpulan}

Pandemi COVID-19 yang melanda ke seluruh provinsi di Indoneisa telah memakan korban ribuan nyawa. Kebijakan penanganan COVID-19 yang sedianya diharapkan dapat menghadap laju persebaran, namun pada kenyataannya tidak mendapatkan hasil signifikan pada tahun 2020. Melalui analisis dari esensi fundamental teori sociological jurisprudence Roscoe Pound, maka kebijakan penanganan COVID-19 seyogyanya dijalankan dengan mendasarkan kepada empat elemen dasar yaitu pertama bahwasanya hukum yang akan disusun hendaknya didahului oleh sebuah kajian multidispliner yang matang; kedua, perumusan regulasi atau produk hukum terkait kebijakan penanganan COVID-19 harus diselaraskan dengan aspek keilmuan yang lain; ketiga, implementasi produk hukum sebagai dasar kebijakan penanganan COVID-19 seyogyanya berjalan dengan efektif; dan keempat bahwa kebijakan pemerintah dalam penanangan COVID-19 harus fokus mengerucut kepada hakikat dasar persoalan apa yang hendak diselesaikan. 


\section{DAFTAR PUSTAKA}

\section{Buku}

Atmosudirjo, S. Prajudi, Hukum Administrasi

Negara, Jakarta: Ghalia Indonesia, 1988.

Bakhri, Syaiful, Ilmu Negara; dalam Pergumulan Filsafat, Sejarah dan Negara Hukum, Depok: RajaGrafindo Persada, 2018.

Ballentine, James A., Ballentine's Law Dictionary, Indianapolis: BobbsMerrill Company, 1916

Belinfante, A. D., dan Boerhanoeddin Soetan Batoeah, Pokok-Pokok Hukum Tata Usaha Negara, Jakarta: Binacipta, 1983.

Hadjon, Philipus M., dkk, Hukum Administrasi dan Tindak Pidana Korupsi, Yogyakarta: Gadjah Mada University Press, 2012.

Kusnardi, Moh., dan Bintang R. Saragih, Ilmu Negara, Jakarta: Gaya Media Pratama, 2008 ,

Lubis, M. Solly, Kebijakan Publik, Bandung: Mandar Maju, 2007.

Marbun, S. F., dan Mahfud MD, Pokokpokok Hukum Administrasi Negara, Yogyakarta: Liberty, 1987.

Mawardi, Irvan, Dinamika Sengketa Hukum Administrasi di Pemilukada; Mewujudkan Electoral Justice dalam Kerangka Negara Hukum Demokratis, Yogyakarta: Rangkang Education, 2014.
Muchsan, Beberapa Catatan Tentang Hukum Administrasi Negara dan Peradilan Administrasi Negara di Indonesia, Yogyakarta: Liberty, 1981. , Peradilan Administrasi Negara, Yogyakarta: Liberty, 1981.

Roscoe Pound, Social Control through Law, New Brunswick: Transaction Publishers, 1997. , The Ideal Element in Law, Indianapolis: Liberty Fund, 2002.

Sadjijono, H., Bab-bab Pokok Hukum Administrasi Negara, Yogyakarta: LaksBang Pressindo, 2001.

Samidjo, , Ilmu Negara, Bandung: Armico, 1986.

Saputra, M. Nata, Hukum Administrasi Negara, Jakarta: Rajawali, 1988.

Soehino, Ilmu Negara, Yogyakarta: Liberty, 2005.

\section{Kumpulan tulisan dalam Buku}

Reza Banakar and Max Travers, "Law, Sociology, and Method" in Theory and Method in Socio-Legal Research, edited by Reza Banakar and Max Travers, Oxford; Hart Publishing, 2005.

Martin Innes, "The Art, Craft, and Science of Policing", in The Oxford Handbook of Empirical Legal Research, edited by Peter Cane and Herbert M. Kritzer, Oxford: Oxford University Press, 2010. pp. 13-33. 


\section{Jurnal}

Gardner, James A., "The Sociological Jurisprudence of Roscoe Pound (Part I)", Vill. L. Rev., Vol. 7, Issue 1 (1961), pp. $1-26$

Hermawan, Sapto, dan Herman, "Kajian Terhadap Tindakan Administrasi Pada Kekuasaan Yudikatif Pasca Berlakunya Undang-Undang Administrasi Pemerintahan", Jurnal Legislasi Indonesia, Vol. 18, No. 1, (2021): 59-80.

Masotti, Louis H., "Theory and Application of Roscoe Pound's Sociological Jurisprudence: Crime Prevention or Control?", U. Mich. J. L. REFORM, Vol. 2 (1969), pp. 431-449.

Nowotny, Kathryn., Zinzi Bailey, Marisa Omori, and Lauren BrinkleyRubinstein, "COVID-19 Exposes Need for Progressive Criminal Justice Reform", Am. J. Public Health., Vol. 10, No. 7, (2020), pp. 967-968

Pound, Roscoe, "The Scope and Purpose of Sociological Jurisprudence III", Harvard Law Review, Vol. 25, No. 6, (Apr., 1912), pp 489-516.

, "Mechanical Jurisprudence",

Columbia Law Review, Vol. 8, Issue 8, (1908), pp. 605-623.

, "Law in Books and Law in Action", American Law Review Vol. 44, Issue 1, (January-February 1910), pp. 12-36.
, "The Need of a Sociological

Jurisprudence", Crime \& Delinquency, Volume 10, Issue 4, (October 1, 1964) pp. 385-397

Tamanaha, B., "Sociological Jurisprudence Past and Present", Law \& Social Inquiry, Vol. 45, Issues 2 (2020), pp. 493-520.

Šlapkauskas, Vytautas, "The Significance of the Sociological Approach to Law for the Development of Jurisprudence", Societal Studies, Vol. 4, No. 8, (2010), pp. 167-181.

\section{Peraturan Perundang-Undangan}

Undang-Undang Negara Republik Indonesia Nomor 6 Tahun 2018 tentang Kekarantinaan Kesehatan (Lembaran Negara Republik Indonesia Tahun 2018 Nomor 128).

Peraturan Pemerintah Pengganti UndangUndang Republik Indonesia Nomor 1 Tahun 2020 tentang Kebijakan Keuangan Negara dan Stabilitas Sistem Keuangan untuk Penananganan Pandemi Corona Virus Disease2019 (COVID-19) dan/atau dalam rangka Menghadapi Ancaman yang Membahayakan Perekonomian Nasional dan/atau Stabilitas Sistem Keuangan (Lembaran Negara Republik Indonesia Tahun 2020 Nomor 87).

Peraturan Pemerintah Republik Indonesia Nomor 21 Tahun 2020 tentang Pembatasan Sosial Berskala Besar 
dalam Rangka Percepatan Penanganan Corona Virus Disease2019 (COVID19), (Lembaran Negara Republik Indonesia Tahun 2020 Nomor 91).

Keputusan Presiden Nomor 7 Tahun 2020 tentang Gugus Tugas Percepatan Penanganan Corona Virus Disease2019 (COVID-19), (Surat Keptusan Nomor $010737 \mathrm{~A})$.

Keputusan Presiden Nomor 9 Tahun 2020 tentang Perubahan atas Keputusan Presiden Nomor 7 Tahun 2020 tentang Gugus Tugas Percepatan Corona Virus
Disease2019 (COVID-19), (Surat Keputusan Nomor 022813 A).

Keputusan Presiden Republik Indonesia Nomor 11 Tahun 2020 tentang Penetapan Kedaruratan Kesehatan Masyarakat Corona Virus Disease2019 (COVID-19), (Surat Keputusan Nomor $031030 \mathrm{~A})$.

Keputusan Presiden Republik Indonesia Nomor 12 Tahun 2020 tentang Penetapan Bencana Nonalam Penyebaran Corona Virus Disease2019 (COVID-19), (Surat Keputusan Nomor $010750 \mathrm{~A})$. 